\title{
Tumour necrosis factor gene polymorphisms in Egyptian patients with rheumatoid arthritis and their relation to disease activity and severity
}

\author{
HEBA M. ZAGHLOL ${ }^{1}$ SANAA ABDELSHAFY $Y^{1}, R A B A B$ A. MOHAMED ${ }^{l}$, ENAS A. ABDELALEEM ${ }^{2}$
}

'Department of Clinical Pathology, Faculty of Medicine, Beni Suef University, Beni Suef, Egypt

${ }^{2}$ Department of Rheumatology and Rehabilitation, Faculty of Medicine, Beni Suef University, Beni Suef, Egypt

\begin{abstract}
Aim of the study: The present case control study was conducted to assess the association of LTA $252 A>G, T N F-\alpha 308 G>A$, and TNF- $\alpha 1031$ T $>C$ gene polymorphisms with rheumatoid arthritis (RA), and their involvement in disease activity and severity.

Material and methods: A total of 70 Egyptians, including 35 RA patients and 35 healthy control individuals, were included in the study. The RA patients comprised 34 females and one male. Cases with RA were diagnosed by a rheumatologist and fulfilled the 2010 ACR/EULAR criteria. Modified disease activity score (DAS28) was used to assess disease activity. Van Der Heijde-modified Sharp score (vdHSS) was used to assess radiological changes for assessment of disease severity. PCR-RFLP was used to detect the association of LTA $252 \mathrm{~A}>\mathrm{G}, T N F-\alpha 308 \mathrm{G}>A$, and TNF- $\alpha 1031 T>C$ gene polymorphisms with RA.

Results: TNF- $\alpha 308 \mathrm{G}$ allele and TNF- $\alpha 308 \mathrm{GG}$ genotype were significantly higher in RA patients compared to healthy control subjects ( $p=0.04$ and $p=0.001$, respectively). TNF- $\alpha 308 \mathrm{G}$ allele and $G G$ genotype were significantly higher in the RA non-remission group compared to the remission group $(p=0.008, p<0.001)$. Patients with the TNF- $\alpha 308$ AG genotype had higher mean of Sharp score compared to the patients with the $G G$ and $A A$ genotypes $(p=0.007)$. There was no significant association between LTA $252 A>G$ and TNF- $\alpha 1031$ T>C gene polymorphisms and RA.

Conclusions: Our results suggest that TNF- $\alpha 308$ G/A gene polymorphism is genetically associated with $R A$ and involved in disease activity and severity in Egyptian patients.
\end{abstract}

Key words: rheumatoid arthritis, genetic susceptibility, TNF polymorphisms, polymerase chain reaction - restriction fragment length polymorphism (PCR-RFLP).

(Centr Eur J Immunol 2018; 44 (3): 277-284)

\section{Introduction}

Rheumatoid arthritis (RA) is a chronic autoimmune disease that affects $1 \%$ of the population worldwide [1]. It is a systemic disease that involves the joints, organs, and other areas of the body such as the skin, eyes, heart, lungs, kidney, and spleen $[2,3]$.

RA displays complex inheritance resulting from an intricate interplay between an individual's environmental and genetic background [4]. It has a multifactorial aetiology, including a wide spectrum of clinical manifestations, variability in disease, progression, severity, and response to therapies [5].

Increased expression of pro- and anti-inflammatory cytokines detected in the affected tissues and serum of RA patients clearly illustrates the role of cytokines in the aetio- pathology of RA [6]. Tumour necrosis factor (TNF), a proinflammatory cytokine, has been shown to play a significant role in the pathogenesis of multiple autoimmune diseases including RA [6-8].

TNF- $\alpha$ and lymphotoxin alpha (LTA) are closely related cytokines that share $30 \%$ of amino acid residues and have the same cell surface receptor [9]. Nedwin et al. [10] reported that the TNF- $\alpha$ and LTA genes are positioned in tandem on chromosome 6 between the class I and class II cluster of the major histocompatibility complex (chromosome 6p21.1$6 \mathrm{p} 21.3$ ). The proinflammatory cytokine TNF- $\alpha$ is one of the cardinal factors involved in RA inflammatory state [7]. TNF- $\alpha$ pleiotropic biological activities are mediated binding to TNF receptors (TNFR) type I and II [11].

Correspondence: Enas A. Abdelaleem MD, Department of Rheumatology and Rehabilitation, Faculty of Medicine, Beni Suef University, Kornish Elnile, Borg Elsafa, 002082 Beni Suef, Egypt, e-mail: dr.enas2000@ gmail.com Submitted: 3.12.2016; Accepted: 24.01.2017 
TNF- $\alpha$ plays a pivotal role in inflammation by inducing the expression of other proinflammatory molecules, chemotactic cytokines, and adhesion factors [12-14]. In vivo and in vitro studies have illustrated that high levels of $\mathrm{TNF}-\alpha$ lead to exacerbation of the inflammatory response. This, together with its strong immunomodulatory activities, has been suggested to be important in the pathogenesis of various diseases such as asthma, systemic lupus erythematosus (SLE), and RA [7, 15, 16].

Amongst the five polymorphisms (at positions +691 , $-238,-308,-851$, and -857) of TNF- $\alpha 308$ gene, which were detected by PCR-single strand conformation polymorphism (PCR-SSCP) analysis, TNF- $\alpha-308$ polymorphism has been reported to be associated with autoimmune diseases including RA $[14,17]$. The genetic variation on position -308 resulted in two allelic forms in which the existence of guanine (G) defines the common variant, and the existence of adenine (A) determines the less common one. LTA, which is linked closely to TNF- $\alpha$, has also been shown to contribute to the susceptibility of multiple autoimmune diseases [ 18 , 19]. A polymorphism has been detected at position +252 within the first intron of the TNF- $\beta$ gene, consisting of a $G$ $(\mathrm{LTA}+252 \mathrm{G})$ on one allele and an A $(\mathrm{LTA}+252 \mathrm{~A})$ on the alternate allele. The presence of $\mathrm{G}$ at this position determined the mutant allele known as LTA*1 (allele-1), which is the less frequent allele in white subjects and is associated with increased TNF- $\alpha$ and LTA production [20, 21].

A study of a Japanese population has indicated that LTA (+252) polymorphism together with HLADRB $1 * 0405$ may have an influence on the predisposition to RA [22]. To the best of our knowledge there are only two cohorts elucidating the role of $T N F-\alpha 308$ $G / A$ polymorphism in RA patients in Egypt. On the other hand, there are no reports investigating the roles of $T N F-\alpha$ $1031 T>C$ and LTA $252 A>G$ gene polymorphisms among Egyptian RA patients. Given the known importance of TNF gene in inflammatory and/or immune functions and the variation in susceptibility to immune disorders in different ethnic groups, we investigated the possible association between LTA $252 A>G, T N F-\alpha 308 G>A$, and $T N F-\alpha 1031 T>C$ polymorphisms and susceptibility to RA in Egyptian patients. In addition, we investigated the association of these polymorphisms with disease activity and severity.

\section{Material and methods}

\section{Patients}

A total of 70 Egyptian persons, including 35 cases and 35 control subjects, were included in the study. The RA patients comprised 34 females and one male. The RA patients were recruited from the outpatient clinic of the Rheumatology and Rehabilitation Department of Beni Suef University Hospital, Egypt, between March 2014 and January 2015. Cases with RA were diagnosed by a rheumatologist and fulfilled the 2010 ACR/EULAR criteria for diagnosis of RA [23]. The healthy control subjects were unrelated Egyptian ageand sex-matched individuals who had no family history of autoimmune diseases. The control group lived in the same geographical area and had the same ethnic origin as the patients. All cases and control subjects were informed of the purpose of the study, and their consent was obtained. The local Ethics Committee approved the study.

\section{Clinical and laboratory assessment}

Blood samples were obtained from all patients for determination of erythrocyte sedimentation rate (ESR; Westergreen), C-reactive protein (CRP), and rheumatoid factor (RF) by semi-quantitative latex (AVITEX ${ }^{\circledR}$ CRP and AVITEX® RF, Omega Diagnostics). CRP was considered positive when $>6 \mathrm{mg} / \mathrm{l}$ while $\mathrm{RF}$ wass considered positive at $\geq 8 \mathrm{IU} / \mathrm{ml}$. Anti-cyclic citrullinated peptide (anti-CCP) was determined using enzyme-linked immunosorbent technique (ELISA) using QUANTA Lite ${ }^{\circledR}$ CCP3IgG ELISA, INOVA Diagnostics. According to the manufacturer's protocol, serum was considered positive when the reading was $\geq 20$ units.

The modified disease activity score DAS28 was calculated for all patients [24]. DAS28 score of higher than 5.1 is indicative of high disease activity, whereas a DAS28 below 3.2 indicates low disease activity. A patient is considered in remission if the DAS28 score is lower than 2.6.

In all patients, plain radiographs of both hands and feet in the posteroanterior projection were obtained. Van Der Heijde-modified Sharp score (vdHSS) was used to assess radiological changes [25].

\section{Genotyping}

Genomic DNA was extracted from EDTA anti-coagulated whole blood using QIAamp DNA Mini Kit (Cat. no. 51104, QIAGEN) according to the manufacturer's protocol. The three sequences flanking TNF- $\alpha 1031 \mathrm{~T}>\mathrm{C}$, TNF- $\alpha 308 \mathrm{G}>\mathrm{A}$, and LTA $252 \mathrm{~A}>\mathrm{G}$ single nucleotide polymorphisms were amplified by polymerase chain reaction (PCR). Genotyping of these polymorphisms was determined by a restriction fragment length polymorphism (RFLP) assay [26].

The 270-bp region of the TNF- $\alpha 1031$ gene, encompassing the 1031T/C polymorphism site, was amplified via polymerase chain reaction (PCR) using the sense (5'-GGGGAGAACAAAAGGATAAG) and antisense (5'-CCCCATACTCGACTTTCATA) primer pair [27]. The total reaction volume was $25 \mu \mathrm{l}$ : $5 \mu \mathrm{l}$ DNA, $12.5 \mu \mathrm{l}$ Dream Taq green PCR master mix (Fermentas), $1 \mu \mathrm{l}$ of each primer and $5.5 \mu \mathrm{l}$ nuclease-free water. Initially, the PCR reaction was subjected to denaturation for $5 \mathrm{~min}$ at $95^{\circ} \mathrm{C}$, followed by 30 cycles of amplification $\left(30 \mathrm{~s}\right.$ at $95^{\circ} \mathrm{C}$, $30 \mathrm{~s}$ at $55^{\circ} \mathrm{C}$, and $30 \mathrm{~s}$ at $72^{\circ} \mathrm{C}$ ). A final elongation step 
$\left(5 \mathrm{~min}\right.$ at $72^{\circ} \mathrm{C}$ ) was applied at the end of the 30 cycles [28]. The PCR is followed by digestion with the restriction enzyme BbsI (Thermo Scientific Cat. no. FDo574) according to the manufacturer's protocol (C allele, 159 and 111 bp; T allele, 270 bp) (Fig. 1) [28]. Digested PCR fragments were separated by $4 \%$ agarose gel electrophoresis stained with ethidium bromide followed by ultraviolet visualisation.

The primers (5'-AGGCAATAGGTTTTGAGGGCCAT-3') and (5'TCCTCCCTGCTCCGATTCC G-3') were used to amplify the 107-bp DNA fragment of the TNF- $\alpha 308 \mathrm{G}>$ A polymorphism. The total PCR reaction mixture was $25 \mu \mathrm{l}: 5 \mu \mathrm{l}$ DNA, $12.5 \mu \mathrm{l}$ Dream Taq green PCR master mix (Fermentas), $1 \mu$ of each primer and $5.5 \mu \mathrm{l}$ nuclease-free water. The PCR Cycling conditions for TNF- $\alpha 308 \mathrm{G}>\mathrm{A}$ were performed according to the protocol described by Bonyadi et al: 5 min for initial denaturation at $95^{\circ} \mathrm{C} ; 35$ cycles at $95^{\circ} \mathrm{C}$ for $1 \mathrm{~min}$ for denaturation, $30 \mathrm{~s}$ at $65^{\circ} \mathrm{C}$ for annealing and $30 \mathrm{~s}$ at $72^{\circ} \mathrm{C}$ for extension, followed by $5 \mathrm{~min}$ at $72^{\circ} \mathrm{C}$ for final extension [28]. After amplification, PCR products were digested (at $37^{\circ} \mathrm{C}$ ) by NcoI (Themo Scientific Cat. no. FD0574) according to the manufacturer's protocol ( $\mathrm{G}$ allele, 87 and $20 \mathrm{bp}$; A allele, 107 bp) (Fig. 2) [28]. Digested PCR products were electrophoresed in $4 \%$ agarose gel stained with ethidium bromide and followed by ultraviolet visualisation. Primers (5' -CCGTGCTTCGTGCTTTGGACTA-3') and (5'AGAGCTGGTGGGGACATGT CT G-3') were used to amplify the 740-bp DNA fragment to genotype the LTA $252 \mathrm{~A}>\mathrm{G}$ polymorphism. The total PCR reaction mixture was $25 \mu \mathrm{l}: 5 \mu \mathrm{l}$ DNA, $12.5 \mu \mathrm{l}$ Dream Taq green PCR master mix (Fermentas), $1 \mu \mathrm{l}$ of each primer and $5.5 \mu \mathrm{l}$ nuclease-free water. The PCR cycling conditions were performed according to the protocol described by Cabrara et al. [29] with a slight modification: initial denaturation at $95^{\circ} \mathrm{C}$ for 5 minutes followed by 35 cycles of amplification: $94^{\circ} \mathrm{C}$ for $45 \mathrm{sec}$, $62.5^{\circ} \mathrm{C}$ for $45 \mathrm{sec}$, and a final extension at $72^{\circ} \mathrm{C}$ for $1.5 \mathrm{~min}$. PCR products were digested (at $37^{\circ} \mathrm{C}$ ) by NcoI (Thermo Scientific Cat. no. FD0574) according to the manufacturer's protocol. Digested PCR products were electrophoresed in $4 \%$ agarose gel stained with ethidium bromide and followed by ultraviolet visualisation. The digested products generated $185 \mathrm{bp}$ and $555 \mathrm{bp}$ bands for the G allele and a 107 bp band for the A allele (Fig. 3) [29].

\section{Statistical analysis}

The collected data review, coding, and statistical analysis was done using SPSS software (Statistical Package for Social Science; SPSS Inc., Chicago, IL, USA) version 16 for Microsoft Windows. Mean, median, range, and standard deviation were calculated to measure central tendency and dispersion of quantitative data, while the frequency of occurrence was calculated to measure qualitative data. Student's $t$-test was used to determine the significance of the difference between two

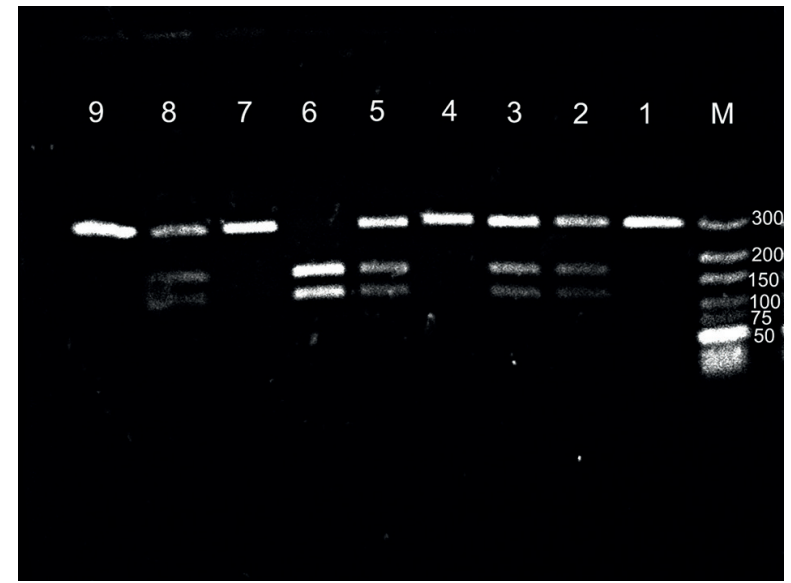

Fig. 1. PCR-RFLP analysis of TNF 1031 gene polymorphism using BbsI restriction enzyme. M: DNA molecular weight marker: (50 bp, 75 bp, 100 bp, 150 bp, 200 bp, $300 \mathrm{bp}$ ), lanes 1, 4, 7, 9: wild type (TT): 1 band at $270 \mathrm{bp}$, lane 6: homozygous mutant type (CC): 2 bands at 111 and $159 \mathrm{bp}$, lanes 2, 3, 5, 8: heterozygous mutant type (TC): 3 bands at $111 \mathrm{bp}, 159 \mathrm{bp}$, and $270 \mathrm{bp}$

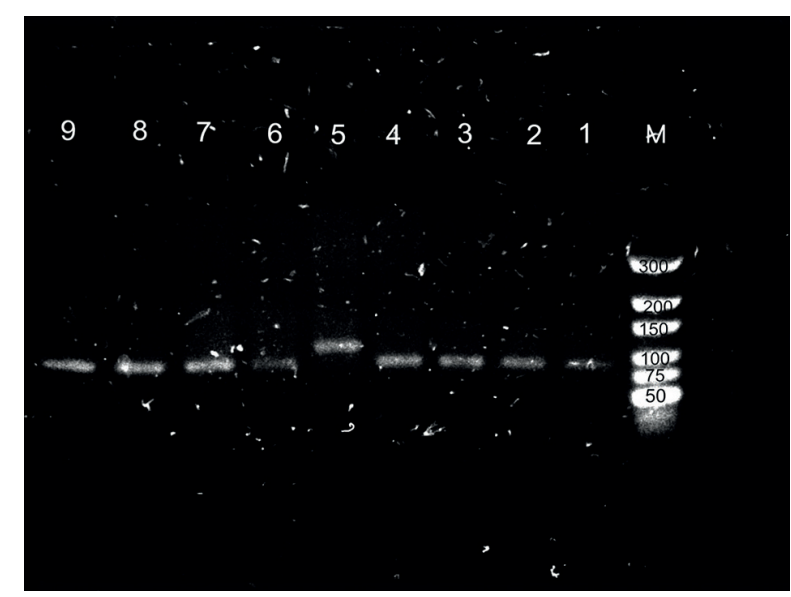

Fig. 2. PCR-RFLP analysis of TNF 308 gene polymorphism using NcoI restriction enzyme. M: DNA molecular weight marker: (50 bp, 75 bp, 100 bp, 150 bp, 200 bp, $300 \mathrm{bp}$ ), lanes 1, 2, 3, 4, 6, 7, 8, 9: wild type (GG): 2 bands at $87 \mathrm{bp}$ and $20 \mathrm{bp}$, lane 5: homozygous mutant type (AA): 1 band at $107 \mathrm{bp}$

means, $\chi^{2}$ was carried out for comparison of qualitative data, and Fisher's exact test was used when the cell count was less than 5. Odds ratios (ORs) with $95 \%$ confidence intervals (CI) were calculated whenever applicable, to test the association between genotype and RA. Analysis of variance (ANOVA) test was used to determine the difference between more than two means. The significance of the OR was calculated using a $2 \times 2$ contingency table. Genotype distributions were compared with those expected for samples from populations in 


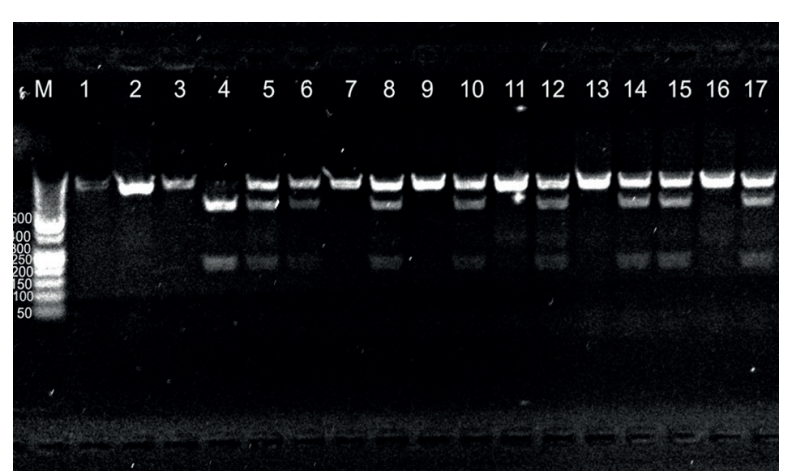

Fig. 3. PCR-RFLP analysis of LTA 252 gene polymorphism using NcoI restriction enzyme. M: DNA molecular weight marker: (50 bp, 100 bp, 150 bp, 200 bp, .., 500 bp), lanes 1, $2,3,7,9,11,13,16$ : wild type (AA): 1 band at $750 \mathrm{bp}$, lanes $5,6,8,10,12,14,15,17$ : heterozygous mutant type (AG): 3 bands at $185 \mathrm{bp}, 555 \mathrm{bp}$, and $750 \mathrm{bp}$, lane 4: homozygous mutant type (GG): 2 bands at $185 \mathrm{bp}$ and $555 \mathrm{bp}$

Hardy-Weinberg equilibrium using an $\chi^{2}$ test $(1 \mathrm{df})$. The level of significance was taken at a $p$-value of $<0.05$.

\section{Results}

The demographic, clinical, and laboratory data of RA patients and control group are shown in Table 1 .

Concerning LTA $252 A>G$ gene polymorphism, the genotype frequencies of RA patients and healthy controls conformed to the Hardy-Weinberg equilibrium ( $p=0.2531$ and $p=0.224$, respectively). Similarly, for the TNF- $\alpha 1031$ $T>C$ gene polymorphism, the genotype frequencies of RA patients and healthy controls conformed to the Hardy-Weinberg equilibrium ( $p=0.97 ; p=0.13$, respectively). As regards the $T N F-\alpha 308 A>G$ gene polymorphism, the genotype frequencies for cases showed deviation from $\operatorname{HWE}(p=0.0019)$, while the genotype frequencies of controls conformed to HWE $(p=0.08)$ (Table 2).

Analysis of the distribution of TNF- $\alpha 308$ G/A revealed that the frequency of the $\mathrm{G}$ allele was higher than the $\mathrm{A}$ allele in the non- remission group. On the other hand, only two patients carrying the A allele were in remission, and there were no patients in remission carrying the A allele. The difference between the two groups was statistically significant $(p=0.008)$. On comparing the distribution TNF- $\alpha 308$ genotypes in both remission and non-remission group patients, the GG genotype was more frequently represented than the AG genotype and the AA genotypes, respectively, and the difference was highly statistically significant $(p<0.001)$ (Table 3 ). Analysis showed that the frequency of distribution of alleles and genotypes in TNF- $\alpha 1031$ T/C and $+252 \mathrm{~A} / \mathrm{G}$ polymorphism was statistically non-significant (Table 3 ).

On comparing the frequency of distribution of TNF- $\alpha$ 308 genotypes with disease severity, we detected that the patients with heterozygous mutant type (AG) had higher Sharp
Table 1. Demographic, clinical, and laboratory data of rheumatoid arthritis patients and control group

\begin{tabular}{|c|c|c|c|c|}
\hline $\begin{array}{l}\text { Demographic } \\
\text { and clinical } \\
\text { data }\end{array}$ & $\begin{array}{c}\text { Cases } \\
(n=35)\end{array}$ & $\begin{array}{l}\text { Controls } \\
(n=35)\end{array}$ & $\begin{array}{c}\text { Significance } \\
\text { test }\end{array}$ & $p$-value \\
\hline \multicolumn{3}{|l|}{ Age } & \multirow[t]{3}{*}{$t=1.60$} & \multirow[t]{3}{*}{0.112} \\
\hline Mean \pm SD & $45.63 \pm 13.93$ & $40.51 \pm 12.63$ & & \\
\hline Range & $20-70$ & $22-65$ & & \\
\hline \multicolumn{3}{|l|}{ Sex, $n(\%)$} & \multirow[t]{3}{*}{$\chi^{2}=0.348$} & \multirow[t]{3}{*}{0.555} \\
\hline Female & $34(97.1)$ & 33 (94.3) & & \\
\hline Male & $1(2.9)$ & $2(5.7)$ & & \\
\hline
\end{tabular}

Disease duration (year)

\begin{tabular}{lc}
\hline Mean \pm SD & $8.49 \pm 6.95$ \\
\hline Median & 6 \\
\hline Range & $1-30$ \\
\hline Sharp score & \\
\hline Mean \pm SD & $37.31 \pm 26.40$ \\
\hline Median & 30 \\
\hline Range & $10-90$ \\
\hline DAS28 & \\
\hline Mean \pm SD & $4.77 \pm 1.44$ \\
\hline Range & $2.30-7.75$ \\
\hline
\end{tabular}

ESR

\begin{tabular}{lc}
\hline Mean \pm SD & $56.40 \pm 22.74$ \\
\hline Range & $10-100$ \\
\hline CRP & $17 / 35$ \\
positivity & $(48.6 \%)$ \\
\hline RF & $25 / 35$ \\
positivity & $(71.4 \%)$ \\
\hline Anti-CCP & $29 / 35$ \\
positivity & $(82.9 \%)$ \\
\hline
\end{tabular}

Significant difference (p-value < 0.05), DAS - disease activity score, ESR erythrocyte sedimentation rate, $C R P-C$-reactive protein, $R F-$ rheumatoid factor, anti-CCP - anti-cyclic citrullinated peptide

score than the patients with the wild type (GG) genotype and the homozygous mutant (AA) genotype, respectively, and the difference was statistically significant ( $p=0.007$ ) (Table 4). On the other hand, analysis of the frequency of distribution of genotypes in TNF- $\alpha 1031$ and LTA +252 polymorphism according to disease severity was statistically non-significant ( $p=0.105$ and $p=0.691$, respectively) (Table 4).

We did not detect any association between the distribution of TNF- $\alpha 308$, TNF- $\alpha$ 1031, and LTA252 genotypes and age/ sex of patients disease duration, CRP, RF, and anti-CCP positivity (data not shown).

\section{Discussion}

RA is a complex, multifactorial, inflammatory disease of unknown aetiology with considerable variability. Both 
Table 2. Comparison of TNF- $\alpha$ and TNF- $\beta$ polymorphisms between Egyptian rheumatoid arthritis patients and healthy controls

\begin{tabular}{|c|c|c|c|c|c|}
\hline & Cases $(n=35)$ & Controls $(n=35)$ & $\begin{array}{l}\text { Odds ratio and } 95 \% \\
\text { confidence interval }\end{array}$ & $\chi^{2}$ & $p$-value \\
\hline \multicolumn{6}{|c|}{ TNF- $\alpha 308, n(\%)$} \\
\hline GG & $30(85.7)$ & $19(54.3)$ & Reference & & $<0.001^{*}$ \\
\hline AG & $3(8.6)$ & $16(45.7)$ & $8.42(1.9-42.3)$ & 11.32 & 0.266 \\
\hline AA & $2(5.7)$ & $0(0.0)$ & $0-0(0.0-7.18)$ & 1.24 & \\
\hline A & $7(10)$ & $16(22.86)$ & Reference & 4.21 & $0.040^{*}$ \\
\hline G & $63(90)$ & $54(77.14)$ & $2.67(0.94-7.791)$ & & \\
\hline \multicolumn{6}{|c|}{ TNF- $\alpha 1031, n(\%)$} \\
\hline TT & $24(68.5)$ & $21(60.0)$ & Reference & & \\
\hline $\mathrm{TC}$ & $10(28.6)$ & $14(40.0)$ & $0.63(0.20-1.90)$ & 0.85 & 0.355 \\
\hline $\mathrm{CC}$ & $1(2.9)$ & $0(0.0)$ & NA & 0.86 & 0.354 \\
\hline $\mathrm{T}$ & $58(82.86)$ & $56(80.0)$ & Reference & 0.189 & 0.664 \\
\hline $\mathrm{C}$ & $12(17.14)$ & $14(20.0)$ & $1.21(0.47-3.084)$ & & \\
\hline \multicolumn{6}{|c|}{ LTA $252, n(\%)$} \\
\hline AA & $15(42.9)$ & $18(51.4)$ & Reference & & \\
\hline AG & $18(51.4)$ & $16(45.7)$ & $1.35(0.46-3.95)$ & 0.38 & 0.540 \\
\hline GG & $2(5.7)$ & $1(2.9)$ & $2.40(0.15-74.6)$ & 0.50 & 0.481 \\
\hline A & $48(68.57)$ & $52(74.29)$ & Reference & 0.56 & 0.454 \\
\hline G & $22(31.43)$ & $18(25.71)$ & $0.76(0.33-1.67)$ & & \\
\hline
\end{tabular}

environmental and genetic factors have been related to susceptibility to disease initiation as well as outcome of disease course [30]. Fifty per cent of risk of developing RA is attributable to genetic factors [31]. Huge progress has been made in the detection of genetic regions that are characterised by structural variation (single nucleotide polymorphisms); more than 30 genetic regions are associated with the incidence of the occurrence of RA [32].

Single nucleotide polymorphisms are considerable and spread throughout the genome. Such disparities are associated with diversity in the population, susceptibility to diseases, and differential response to medical treatment [33].

Polymorphisms situated within the promoter region of TNF- $\alpha$ and the intron 1 polymorphism of LTA, in particular, have been linked with altered levels of circulating TNF- $\alpha$ [34].

In the present study, on investigating the genetic association of TNF- $\alpha 308 \mathrm{~A} / \mathrm{G}$ and RA, the G allele and the wild type (GG) genotype were more frequently represented among RA patients ( $p=0.040, p<0.001$; respectively). In accordance with our results, Mosaad et al. reported that the $\mathrm{G}$ allele and the GG genotype were more frequently represented among RA patients compared to the healthy control group [35]. Moreover, several studies conducted in other parts of the world are in agreement with our results [36, 37].

However, in contrast to the results of the current study, Hussein et al. [33] reported that TNF 308 AA genotype was more frequently prevalent among the patients and associated with RA susceptibility. Similarly, in contrast to our findings, numerous studies showed significantly higher frequency of allele A or genotype AA in RA patients compared to the control group, suggesting that TNF- $\alpha$ 308 A allele is a predisposing factor of RA [38-40]. On the other hand, non-significant association between TNF- $\alpha$ 308 polymorphism and RA susceptibility was observed in other case control studies [41, 42].

Our results regarding TNF- $\alpha 308 \mathrm{G} / \mathrm{A}$ polymorphism could be explained by the fact that these differences in findings may be attributed to the ethnicity-related genetic constitution in different populations, which is evident from the significant variability in genotype data of TNF- $\alpha 308$ polymorphism among the healthy subjects of various ethnicities [37]. Hence, the joint gene-environment synergy might be responsible for the considerable differences in the results of polymorphism association studies on RA patients from diversities in ethnicities and/or geographical locations [42]. The difference in results between patient groups in different 
Table 3. Comparison of TNF- $\alpha$ and TNF- $\beta$ polymorphisms distribution according to DAS28 scoring system

\begin{tabular}{|c|c|c|c|c|}
\hline DAS28 & $\begin{array}{l}\text { Remission } \\
\quad(n=1)\end{array}$ & $\begin{array}{l}\text { Non-remission } \\
\quad(n=34)\end{array}$ & $\chi^{2}$ & $p$-value \\
\hline \multicolumn{5}{|c|}{ TNF- $\alpha$ 308, $n(\%)$} \\
\hline GG & $0(0.0)$ & $30(88.2)$ & \multirow[t]{3}{*}{16.98} & \multirow[t]{3}{*}{$<0.001^{*}$} \\
\hline $\mathrm{AG}$ & $0(0.0)$ & $3(8.9)$ & & \\
\hline AA & $1(100)$ & $1(2.9)$ & & \\
\hline A & $2(100)$ & $5(7.4)$ & \multirow[t]{2}{*}{18.53} & \multirow[t]{2}{*}{$0.008^{*}$} \\
\hline G & $0(0.0)$ & 63 (92.6) & & \\
\hline \multicolumn{5}{|c|}{ TNF- $\alpha, n(\%)$} \\
\hline $\mathrm{CC}$ & $0(0.0)$ & $1(2.9)$ & \multirow[t]{3}{*}{0.47} & \multirow[t]{3}{*}{0.790} \\
\hline $\mathrm{TC}$ & $0(0.0)$ & $10(29.4)$ & & \\
\hline TT & $1(100)$ & $23(67.7)$ & & \\
\hline $\mathrm{C}$ & $0(0.0)$ & $12(17.6)$ & \multirow[t]{2}{*}{0.43} & \multirow[t]{2}{*}{0.513} \\
\hline $\mathrm{T}$ & $2(100)$ & $56(82.4)$ & & \\
\hline \multicolumn{5}{|c|}{ LTA $252, n(\%)$} \\
\hline GG & $0(0.0)$ & $2(5.9)$ & \multirow[t]{3}{*}{0.97} & \multirow[t]{3}{*}{0.615} \\
\hline AG & $1(100)$ & $17(50.0)$ & & \\
\hline AA & $0(0.0)$ & $15(44.1)$ & & \\
\hline G & $1(50.0)$ & $21(30.9)$ & \multirow[t]{2}{*}{0.33} & \multirow[t]{2}{*}{0.532} \\
\hline A & $1(50.0)$ & 47 (79.1) & & \\
\hline
\end{tabular}

Egyptian governorates might be attributed to differences in study design, mean duration of RA, and sample size.

In the current study, allele and genotype frequency distribution analysis revealed that TNF- $\alpha 1031$ T/C SNP is not associated with the incidence of RA in our study group. In agreement, Karry et al. found no significant difference between RA patients and healthy controls [27].

Although there is a plethora of literature regarding the role of TNF- $\alpha$ polymorphism in the pathogenesis of a variety of autoimmune diseases as RA, only a few studies have reported on the role of LTA in the pathogenesis of RA.

LTA belonging to the surrounding of TNF- $\alpha$ locus has indeed been shown to play a significant role in the pathogenesis multiple autoimmune diseases, including RA. Immunological studies on LTA showed its close similarity to TNF- $\alpha$ in terms of their pro-inflammatory and apoptotic activity [18].

A polymorphism has been detected at position +252 residing within the first intron of the LTA gene, consisting of nucleotides guanine (LTA+252G) on one allele and adenine $(\mathrm{LTA}+252 \mathrm{~A})$ on the alternate allele [37].

In the current study, LTA $252 \mathrm{~A}>\mathrm{G}$ allele and genotype frequency distribution were similar between patients and healthy controls. In accordance, Al Rayes et al. and that
Table 4. Comparison between disease severity (represented by Sharp score) and gene polymorphisms in RA patients

\begin{tabular}{|c|c|c|c|}
\hline Genotypes & $\begin{array}{l}\text { Sharp score } \\
(\text { mean } \pm \text { SD })\end{array}$ & $\begin{array}{l}\text { ANOVA test } \\
\qquad(F)\end{array}$ & $p$-value \\
\hline \multicolumn{2}{|l|}{ TNF- $\alpha 308$} & 5.79 & $0.007^{*}$ \\
\hline GG & $34.13 \pm 24.24$ & & \\
\hline AG & $80.00 \pm 10.00$ & & \\
\hline AA & $21.00 \pm 12.72$ & & \\
\hline \multicolumn{2}{|l|}{ TNF- $\alpha 1031$} & 2.42 & 0.105 \\
\hline $\mathrm{CC}$ & $90.00 \pm 12.01$ & & \\
\hline $\mathrm{CT}$ & $31.50 \pm 24.86$ & & \\
\hline TT & $37.54 \pm 21.18$ & & \\
\hline \multicolumn{2}{|l|}{ LTA 252} & 0.691 & 0.37 \\
\hline GG & $37.50 \pm 24.74$ & & \\
\hline GA & $41.00 \pm 28.67$ & & \\
\hline AA & $32.87 \pm 24.75$ & & \\
\hline
\end{tabular}

"Significant difference $(p<0.05)$, the total number of cases analysed for each gene is 35

the frequency of the $\mathrm{G}$ allele were similarly distributed between cases and controls [37]. Moreover, Zake et al. reported that both G allele and GG genotype were similarly distributed in cases and controls [43].

In contrast, Santos et al. [44] reported an association between A allele and RA. These studies showed that TNF- $\beta$ +252 polymorphism together with HLA-DRB $1 * 0405$ has an influence on susceptibility to RA. Similarly, Al-Rayes et al. reported that GG genotype of TNF- $\beta(+252)$ polymorphism was more frequent in RA patients as compared to the control group [37].

In the current study, analysis of the genetic influence of TNF- $\alpha 308$ allele and on disease activity represented by DAS28 scoring system revealed that the G allele and GG genotype are more frequently represented in the non-remission group compared to the remission group $(p=0.008$ and $p<0.001$, respectively). This might be related to the influence of the SNPs, detected in genes coding for TNF- $\alpha$ and iNOS, on the severity of the inflammatory process, which might result in modification of RA disease activity [43].

In accordance with the results of the current study, Petra et al. and Hussein et al. indicated a positive association between GG genotype and disease activity [33, 45]. On the other hand, Nemec et al. did not detect an association between TNF- $\alpha 308$ G/A promoter SNP and RA disease activity represented by disease activity score DAS28 scoring system [38].

In the current study, analysis of disease severity represented by Sharp score revealed that regarding TNF- $\alpha 308$ G/A SNP Sharp score was highest among patients carrying the AG genotype compared to patients carrying the AA and GG genotypes ( $p=0.007)$, the heterozygous mutant (AG). The effect of polymorphism on disease severity 
could be explained by differences the rate of TNF- $\alpha$ synthesis. Thus, the production of TNF- $\alpha$ may be associated with TNF- $\alpha$ promoter SNP. In fact, the role of linkage disequilibrium is intense in this area, and it may be difficult to study the role of SNPs separately [38]. Moreover, circulating TNF- $\alpha$ levels might be under a complex regulatory process. Circulating TNF- $\alpha$ level is regulated at different stages: gene transcription, post transcription control of mRNA stability, cleavage of the membrane form to release the soluble form, and the expression of receptors [46].

Our results regarding radiological joint damage were in accordance with Rezaieyazdi et al. [47], who documented the association between heterozygous mutant (AG) genotype with a worse course of the disease. However, in contrast, Nemec et al. [38] reported an association between severe course of RA and TNF- $\alpha 308$ GG genotype. This was also reported by Barton et al. [48], who reported that the $\mathrm{G}$ allele showed a tendency towards worse radiological outcome at five years, as measured by the presence or absence of erosions, in patients with inflammatory arthritis. On the other hand, Mosaad et al. reported that RA patients with A allele tend to have an increased number of erosions [38]. By contrast, there was no significant association between erosive disease and TNF- $\alpha$, in Turkish patients and Polish patients [49].

In the current study, no statistically significant association was found between TNF- $\alpha 1031$ T/C polymorphism and RA disease activity and severity. In agreement with the results of the current study, Barton et al. reported the absence of a significant association between TNF- $\alpha 1031$ and disease severity in RA patients [48]. Contrary to our findings, Karray et al., pointed out that the $\mathrm{C}$ allele and $\mathrm{CC}$ genotype were significantly higher in patients in remission of RA activity than in those from the non-remission group [27]. There was no statistically significant association detected as regards disease activity and severity and LTA 252 SNP. In agreement with our findings, Karray et al. and Al Rayes et al. also found no association with RA activity and severity [27, 37].

\section{Conclusions}

The results of the current study suggest that TNF- $\alpha 308$ G/A SNP can be genetically associated with the susceptibility to RA in our study group and might be involved in both disease activity and severity. Therefore, the TNF molecule might have major genetic and/or functional involvement in the pathogenesis of RA and might also be implicated in disease activity and severity in the Egyptian patients.

\section{Acknowledgements}

The authors wish to thank Dr. Dina Nabil for her kind support throughout the work.

The authors declare no conflict of interest.

\section{References}

1. Raina P, Matha Roo K, Kumar A, et al. (2014): Association of TNF-Alpha-308 G>A polymorphism with rheumatoid arthritis in two north Indian cohorts. Arch Rheumatol 29; 421-249.

2. Goldsby RA, Kindt TJ, Osborne BA (2006): Kuby Immunology, $6^{\text {th }}$ ed. W.H. Freeman \& Company, New York.

3. Mateen S, Zafar A, Moin S, et al. (2016): Understanding the role of cytokines in the pathogenesis of rheumatoid arthritis. Clinica Chemica Acta 455: 161-171.

4. Chen R, Fang M, Cai Q, et al. (2007): Tumor necrosis factor alpha-308 polymorphism is associated with rheumatoid arthritis in Han population of Eastern China. Rheumatol Int 28: $121-126$.

5. Firestein GS (2003): Evolving concepts of rheumatoid arthritis. Nature 423: 356-361.

6. Gambhir D, Lawrence A, Aggarwal A, et al. (2010): Association of tumor necrosis factor alpha and IL-10 promoter polymorphisms with rheumatoid arthritis in North Indian population. Rheumatol Int 30; 1211-1217.

7. Brennan FM, Maini RN, Feldmann M (1992): TNF alpha - a pivotal role in rheumatoid arthritis? Br J Rheumatol 31: 293-298.

8. Feldmann M, Brennan FM, Foxwell BM, Mainin RN (2001): The role of TNF alpha and IL-1 in rheumatoid arthritis. Curr Dir Autoimmun 3: 188-199.

9. Beutler B, Cerami A (1989): The biology of cachectin/ TNF-a primary mediator of the host response. Annu Rev Immunol 7: 625-655.

10. Nedwin GE, Svedersky LP, Bringman TS, et al. (1985): Effect of interleukin 2, interferon-gamma, and mitogens on the production of tumor necrosis factors alpha and beta. J Immunol 135: 2492-2497.

11. Hohmann HP, Remy R, Brockhaus M, van Loon AP (1989): Two different cell types have different major receptors for human tumor necrosis factor (TNF alpha). J Biol Chem 264: 14927-14934.

12. Bradley JR (2008): TNF-mediated inflammatory disease. J Pathol 214: 149-160.

13. Hehlgans T, Pfeffer K (2005): The intriguing biology of the tumour necrosis factor/tumour necrosis factor receptor superfamily: players, rules and the games. Immunology 115: 1-20.

14. Lee YH, Bae SC (2015): Association between TNF- $\alpha$ polymorphisms and susceptibility to rheumatoid arthritis and vitiligo. A meta-analysis. Genet Mol Res 14: 5548-5599.

15. Thomson WM, Edwards SJ, Dobson-Le DP, et al. (2001): IL-1 genotype and adult periodontitis among young New Zealanders. J Dent Res 80: 1700-1703.

16. Aringer M, Smolen JS (2003): SLE - Complex cytokine effects in a complex autoimmune disease: tumor necrosis factor in systemic lupus erythematosus. Arthritis Res Ther 5: 172177.

17. Khanna D, Wu H, Park G, et al. (2006): Association of tumor necrosis factor $\alpha$ polymorphism, but not the shared epitope, with increased radiographic progression in a seropositive rheumatoid arthritis inception cohort. Arthritis and Rheum 54: 1105-1116.

18. Panoulas VF, Nikas SN, Smith JP, et al. (2008): Lymphotoxin $252 \mathrm{~A} / \mathrm{G}$ polymorphism is commonly associated with myocardial infarction in patients with rheumatoid arthritis. Ann Rheum Dis 67: 1550-1556.

19. Boraska V, Zeggini E, Groves CJ, et al. (2009): Family-based analysis of tumor necrosis factor and lymphotoxinalpha tag polymorphism with type 1 diabetes in the population of South Croatia. Hum Immunol 70: 195-199. 
20. Messer G, Spengler U, Jung MC, et al. (1991): Polymorphic structure of the tumor necrosis factor (TNF) locus: an Ncol polymorphism in the first intron of the human TNF-beta gene correlates with a variant amino acid in position 26 and a reduced level of TNF-beta production. J Exp Med 173: 209-219.

21. Abraham LJ, French MAH, Dawkins RL (1993): Polymorphic MHC ancestral haplotypes affect the activity of tumor necrosis factor alpha. Clin Exp Immunol 92: 14-18.

22. Takeuchi F, Nabeta H, Hong GH, et al. (2005): The genetic contribution of the TNFa11 microsatellite allele and the $\mathrm{TNFb}+252 * 2$ allele in Japanese RA. Clin Exp Rheumatol 23: 494-498.

23. Aletaha D, Neogi TT, Silman AJ (2010): 2010 rheumatoid arthritis classification criteria: an American College of Rheumatology/European League Against Rheumatism collaborative initiative. Ann Rheum Dis 69: 1580-1588.

24. Villaverde V, Balsa A, Cantalejo M, et al. (2000): Activity indices in rheumatoid arthritis. J Rheumatol 27: 2576-2581.

25. Van der Heijde DM (1999): How to read radiographs according to the Sharp/van der Heijde method. J Rheumatol 26: 743-745.

26. Avise JC (1994): Molecular markers, natural history and evolution. Chapman and Hall, New York: 511.

27. Karray EF, Bendhifallah I, BenAbdelghani K, et al. (2011): Tumor necrosis factor gene polymorphisms and susceptibility to rheumatoid arthritis in regional Tunisian population. J Infect Dis Immun 3: 30-35.

28. Bonyadi M, Jahanafrooz Z, Esmaeili M, et al. (2009): TNF- $\alpha$ gene polymorphisms in Iranian Azeri Turkish patients with Behcet's Disease. Rheumatol Int 30: 285-289.

29. Cabrara M, Shaw MA, Sharples C, et al. (1995): Polymorphism in Tumor Necrosis Factor Genes Associated with Mucocutaneous Leishmaniasis. Exp Med 182: 1259-1264.

30. Reveille JD (1998): The genetic contribution to the pathogenesis of rheumatoid arthritis. Curr Opin Rheumatol 10: 187-200.

31. van der Woude D, Houwing-Duistermaat JJ, Toes RE, et al. (2009): Quantitative heritability of anti-citrullinated protein antibody-positive and anti-citrullinated protein antibody-negative rheumatoid arthritis. Arthritis Rheum 60: 916-923.

32. Orozco G, Eyre S, Hinks A, et al. (2010): Association of CD40 with rheumatoid arthritis confirmed in a large UK case-control study. Ann Rheum Dis 69: 813-816.

33. Hussein YM, El-Shal AS, Rezk NA, et al. (2013): Influence of interleukin-4 gene polymorphisms and interleukin-4 serum level on susceptibility and severity of rheumatoid arthritis in Egyptian population. Cytokine 61: 849-855.

34. Sharma S, Ghosh B, Sharma SK (2008): Association of TNF polymorphisms with sarcoidosis, its prognosis and tumour necrosis factor (TNF)-alpha levels in Asian Indians. Clin Exp Immunol 151: 251-259.

35. Mosaad YM, Abdelsalam A, El-Bassiony SR (2011): Association of tumour necrosis factor-alpha-308 G/A promoter polymorphism with susceptibility and disease profile of rheumatoid arthritis. Int J Immunogenet 38: 427-433.

36. Balog A, Gal J, Gyulai Z, et al. (2004): Tumor necrosis factor-alpha and heat-shock protein 70-2 gene polymorphisms in a family with rheumatoid arthritis. Acta Microbiol Immunol Hung 51: 263-269.

37. Al-Rayes H, Al-Swailem R, Albelawi M, et al. (2011): TNF- $\alpha$ and TNF- $\beta$ gene polymorphism in Saudi rheumatoid arthritis patients. Clin Med Insights Arthritis Musculoskelet Disord 4: 55-63.
38. Nemec P, Pavkova-Goldbergova M, Stouracova M, et al. (2008): Polymorphism in the tumor necrosis factor- $\alpha$ gene promoter is associated with severity of rheumatoid arthritis in the Czech population. Clin Rheumatol 27: 59-65.

39. Ursum J, van der Weijden MA, van Schaardenburg D, et al. (2010): IL10 GGC haplotype is positively and HLADQA $1 * 05-\mathrm{DQB} 1 * 02$ is negatively associated with radiographic progression in undifferentiated arthritis. J Rheumatol 37: 1431-1438.

40. Stojanović S, Jevtović-Stoimenov T, Stanković A, et al. (2011): Association of TNF-alpha polymorphism (-308 A/G) with high activity of rheumatoid arthritis and therapy response to Etanercept. Srp Arh Celok Lek 139: 784-789.

41. Lee YH, Ji JD, Song GG (2007): Tumor necrosis factor- $\alpha$ promoter $-308 \mathrm{~A} / \mathrm{G}$ polymorphism and rheumatoid arthritis susceptibility: a meta-analysis. J Rheumatol 34: 43-49.

42. Reneses S, González-Escribano MF, Fernández-Suárez A, et al. (2009): The value of HLA-DRB1 shared epitope, -308 tumor necrosis factor-alpha gene promoter polymorphism, rheumatoid factor, anti-citrullinated peptide antibodies, and early erosions for predicting radiological outcome in recent-onset rheumatoid arthritis. J Rheumatol 36: 1143-1149.

43. Zake LN, Cimdina I, Rumba I, et al. (2002): Major histocompatibility complex class I chain related (MIC) A gene, TNFa microsatellite alleles and TNFB alleles in juvenile idiopathic arthritis patients from Latvia. Hum Immunol 63: 418-423.

44. Santos MJ, Fernandes D, Caetano-Lopes J, et al. (2011): Lymphotoxin- $\alpha 252 \mathrm{~A}>\mathrm{G}$ polymorphism: a link between disease susceptibility and dyslipidemia in rheumatoid arthritis? J Rheumatol 38: 1244-1249.

45. Grabar PB, Logar D, Tomšič M, et al. (2009): Genetic polymorphisms modifying oxidative stress are associated with disease activity in rheumatoid arthritis patients. Dis Markers 26: 41-48.

46. Hajeer AH, Hutchinson IV (2001): Influence of TNF alpha gene polymorphisms on TNF alpha production and disease. Hum Immunol 62: 1191-1199.

47. Rezaieyazdi Z, Afshari JT, Sandooghi M, Mohajer F (2007): Tumor necrosis factor $\alpha-308$ promoter polymorphism in patients with rheumatoid arthritis. Rheumatol Int 28: 189-191.

48. Barton A, Platt H, Salway F (2004): Polymorphism in the tumour necrosis factor gene are not associated with severity of inflammatory polyarthritis. Ann Rheum Dis 63: 280-284.

49. Ates O, Hatem G, Hamuryudan V, Topal-Sarikaya A (2008): Tumor necrosis factor-alpha and interleukin-10 gene promoter polymorphism in Turkish rheumatoid arthritis patients. Clin Rheumatol 27: 1243-1248. 